\title{
Effectiveness of Different Precipitated Phosphates as Phosphorus Sources for Plants
}

\author{
A. E. JOHNSTON ${ }^{1 \star}$ and I. R. RICHARDS ${ }^{2}$ \\ 1 IACR-Rothamsted, Harpenden, Hertfordshire, AL5 2JQ, UK \\ 2 Ecopt, Ufford Road, Bredfield, Suffolk, IP13 6AR, UK \\ * Corresponding author e-mail johnny.johnston@bbsrc.ac.uk
}

\begin{abstract}
Eleven precipitated phosphates were evaluated as sources of phosphorus $(P)$ for plant growth by comparing their effectiveness with that of monocalcium phosphate, a source of water-soluble $P$ that is generally considered to be fully plant available. The precipitated phosphates comprised struvites recovered from waste water discharges (mainly magnesium ammonium phosphate), laboratory synthesised struvites, a synthetic iron phosphate and a recovered calcium phosphate. Precipitating phosphates in these forms could be a way for removing $P$ from waste water before it is discharged to rivers, so reducing the risk of eutrophication. Application to agricultural land would be one potential use for such phosphates. Evaluation was by pot experiments with a sandy loam soil and with a sandy clay loam soil using perennial ryegrass as the test crop. The soils differed in $\mathrm{pH}$ (6.6 and 7.1) and in Olsen $P\left(28\right.$ and $\left.11 \mathrm{mg} \mathrm{L}^{-1}\right)$. Measured variables were grass dry-matter (DM) yield and grass $P$ concentration which were used to calculate offtake of $P$ in the harvested grass. DM yields of ryegrass and $P$ offtakes given by the synthetic and recovered struvites were not significantly different statistically either between themselves or to MCP applied at the same rate. On this basis these struvites could be used to recycle $P$ to similar soils and the effect of the P on crop yield should be similar to that of MCP
\end{abstract}

Key words: struvite, $\mathrm{P}$ availability, pot experiment, ryegrass

\section{INTRODUCTION}

In recent decades waste water discharges have become an issue because the $\mathrm{P}$ they contain is one of the sources responsible for the disturbance of the biological balance in some surface fresh waters. Steps can be taken to lessen the amount of soluble P in discharges by precipitating it in various chemical forms. These include magnesium ammonium phosphate $\left(\mathrm{MgNH}_{4} \mathrm{PO}_{4}\right)$ and magnesium potassium phosphate $\left(\mathrm{MgKPO}_{4}\right)$, members of a group of related compounds called struvites. Additionally $\mathrm{P}$ can be precipitated as calcium, iron and aluminium phosphates. The small concentration of $\mathrm{N}(5.6 \%)$ relative to $\mathrm{P}(12.5 \%)$ in magnesium ammonium phosphate indicates that, if this material is to be used on arable crops or grassland, the availability of the $\mathrm{P}$ becomes the more important agronomic factor. The use of struvites as nutrient sources was first proposed by Murray (1858). Much of the recent literature on phosphates, particularly struvites, recovered from waste water has been concerned with their production and potential use in agriculture (Gaterell et al. 2000) but there are few reports of agronomic effectiveness. Koritskaya and Remen (1962) published some results on field crops. Ghosh et al. (1996) reported that struvite was as effective as diammonium phosphate as a P source for gram in India. Goto (1998) in Japan also gave data showing that finely divided struvite was as effective as superphosphate. 
Unlike superphosphate, these precipitated phosphates do not contain water-soluble P. High water solubility and the beneficial effects of superphosphates in increasing crop yields are well recognised by farmers. Nevertheless, some phosphatic fertilisers, for example nitrophosphates, contain less than $90 \%$ of the $\mathrm{P}$ in water-soluble forms yet they are very effective in supplying $\mathrm{P}$ to crops. Thus the solubility of $\mathrm{P}$ in water and the availability of the P to crops are not necessarily closely related.. It is important therefore to test the availability of $\mathrm{P}$ in products with little water-soluble $\mathrm{P}$. It was decided to determine the availability of the $\mathrm{P}$ in a range of recovered phosphates so that appropriate advice could be given to farmers and advisors.

\section{MATERIALS AND METHODS}

\section{Precipitated phosphates}

The 11 precipitated phosphates tested had a range of $\mathrm{P}$ concentrations and were obtained from several sources (Table 1). The two synthetic struvites were made using commercially available ingredients by two different laboratories. The iron phosphate was made in the laboratory using the ferric chloride that would be used by water companies for $\mathrm{P}$ removal from waste water. According to the sponsors of the project, who supplied the precipitated phosphates, the principal $\mathrm{P}$ source in the synthetic struvites and all recovered struvites, except no. 5, was magnesium ammonium phosphate. Recovered struvite no. 5 was magnesium potassium phosphate. The total $\mathrm{P}$ concentration in every material was determined by digestion with mineral acids $\left(\mathrm{HCl} / \mathrm{HNO}_{3}\right)$ followed by analysis using inductively coupled plasma (ICP). Results were expressed as percentage $\mathrm{P}$ in the materials as received, that is without drying. Monocalcium phosphate (MCP) $(24.49 \%$ P) was purchased commercially (Analar grade).

The precipitated phosphates differed in physical form (Table 1) so, to ensure a fair comparison, all materials were passed through a $0.5 \mathrm{~mm}$ (30 mesh) sieve. Some required grinding but others passed through the sieve easily.

\section{Soils used}

The two soils, a sandy loam and a sandy clay loam, were collected fresh, passed through a 4 $\mathrm{mm}$ sieve and each was thoroughly mixed before use. Soil $\mathrm{pH}$ was determined in water (ratio soil:water 1:2.5), readily available P by the Olsen method and organic matter by the Walkley \& Black method.

Soil 1, a sandy loam, had a $\mathrm{pH}$ of 6.6 and contained $28 \mathrm{mg} \mathrm{L}^{-1}$ of Olsen $\mathrm{P}$ and $1.0 \%$ organic carbon (equivalent to $1.7 \%$ organic matter). Soil 2, a sandy clay loam, had a $\mathrm{pH}$ of 7.1 and contained $11 \mathrm{mg} \mathrm{L}^{-1}$ of Olsen $\mathrm{P}$ and $1.8 \%$ organic carbon (equivalent to $3.1 \%$ organic matter). These levels of Olsen $\mathrm{P}$ would be regarded as medium and low for soils 1 and 2 respectively. Details of the soils are shown in Table 2.

\section{Pot experiments}

There were two experiments, of identical design, one for each soil. The 11 precipitated phosphates (Table 1) were applied at a rate equivalent to $0.087 \mathrm{~g} \mathrm{P}$ per pot based on the total $\mathrm{P}$ content of the material as received. MCP was included at 5 rates $(0.044,0.065,0.087,0.109$ and $0.131 \mathrm{~g} \mathrm{P}$ per pot, equivalent to $0.10,0.15,0.20,0.25$ and $0.30 \mathrm{~g} \mathrm{P}_{2} \mathrm{O}_{5}$ per pot ), together with a control treatment which received no $\mathrm{P}$. The $\mathrm{P}$ sources were mixed with the soil $(1 \mathrm{~kg})$ for each pot immediately before sowing perennial ryegrass, $c v$. Vigor $(\mathrm{RvP})$ at $0.37 \mathrm{~g}$ per pot. The total number of treatments was 17 and these were replicated 3 times in a randomised block design giving 51 pots for each soil. 
Table 1: Description of the precipitated phosphates evaluated in the pot experiments

\begin{tabular}{|c|c|c|c|}
\hline Material & Source & $\begin{array}{l}\text { Phosphorus } \\
\text { content \%P }\end{array}$ & Physical form \\
\hline $\begin{array}{l}\text { Synthetic stuvite } \\
\text { no. } 1\end{array}$ & $\begin{array}{l}\text { Laboratory synthesised } \\
\text { struvite provided by Rhodia }\end{array}$ & 12.8 & $\begin{array}{l}\text { White powder, some } \\
\text { clumping into lumps } \\
\text { that easily broke down }\end{array}$ \\
\hline $\begin{array}{l}\text { Synthetic struvite } \\
\text { no. } 2\end{array}$ & $\begin{array}{l}\text { Laboratory synthesised 'pure' } \\
\text { struvite provided by Cranfield } \\
\text { University, UK }\end{array}$ & 13.4 & $\begin{array}{l}\text { White cores, approx } \\
3 \mathrm{~mm} \text { diameter, } \\
\text { crumble to white } \\
\text { powder }\end{array}$ \\
\hline $\begin{array}{l}\text { Recovered } \\
\text { struvite no. 1a }\end{array}$ & $\begin{array}{l}\text { Struvite recovered by the full scale } \\
\text { Unitika process from municipal } \\
\text { sewage works in Japan } \\
\text { (Uneo \& Fujii 2001, Taruya et al. 2000) }\end{array}$ & 12.9 & $\begin{array}{l}\text { Cream coloured small } \\
\text { particles, free flowing }\end{array}$ \\
\hline $\begin{array}{l}\text { Recovered } \\
\text { struvite no. 1b }\end{array}$ & $\begin{array}{l}\text { Struvite recovered by the full scale } \\
\text { Unitika process from municipal } \\
\text { sewage works in Japan } \\
\text { (Uneo \& Fujii 2001, Taruya et al. 2000) }\end{array}$ & 12.8 & $\begin{array}{l}\text { Cream coloured small } \\
\text { particles, free flowing }\end{array}$ \\
\hline $\begin{array}{l}\text { Recovered } \\
\text { struvite no. } 2\end{array}$ & $\begin{array}{l}\text { Struvite recovered from corn steep } \\
\text { liquor by the Audobon Sugar } \\
\text { Institute/Lousiana State University } \\
\text { Agricultural Center, USA, AECI-Bio } \\
\text { pilot process }\end{array}$ & 13.1 & $\begin{array}{l}\text { Fine white powder, } \\
\text { some formation of } \\
\text { lumps that easily } \\
\text { broke down }\end{array}$ \\
\hline $\begin{array}{l}\text { Recovered } \\
\text { struvite no. } 3\end{array}$ & $\begin{array}{l}\text { Struvite recovered from the } \\
\text { Kiakyushu City municipal sewage } \\
\text { treatment plant, Japan, using } \\
\text { seawater as a magnesium source } \\
\text { (Nishihara Co pilot plant) } \\
\text { (Matsumiya et al. 2000) }\end{array}$ & 12.8 & $\begin{array}{lr}\text { Similar to Unitika } \\
\text { material, } & \text { cream } \\
\text { coloured } & \text { small } \\
\text { particles, free flowing }\end{array}$ \\
\hline $\begin{array}{l}\text { Recovered } \\
\text { struvite no. } 4\end{array}$ & $\begin{array}{l}\text { Struvite recovered from carmin red } \\
\text { dye industry waste liquors (CHR } \\
\text { Hansen SA/University of Barcelona) } \\
\text { (Villalba et al. 2001) }\end{array}$ & 8.3 & $\begin{array}{l}\text { Very fine, pale brown } \\
\text { powder, free flowing }\end{array}$ \\
\hline $\begin{array}{l}\text { Recovered } \\
\text { struvite no. } 5\end{array}$ & $\begin{array}{l}\text { Potassium struvite recovered from } \\
\text { veal manure at the full scale plant of } \\
\text { yje Putten agricultural co-operative, } \\
\text { The Netherlands } \\
\text { (Schuiling \&Andrade 1999) }\end{array}$ & 8.6 & $\begin{array}{l}\text { Yellow/brown moist } \\
\text { powder with lumps }\end{array}$ \\
\hline $\begin{array}{l}\text { Recovered } \\
\text { struvite no. } 6\end{array}$ & $\begin{array}{l}\text { Spontaneously occurring deposit } \\
\text { material (mainly struvite) from } \\
\text { digestor outflow pipes at the } \\
\text { Wassmansdorff municipal sewage } \\
\text { works, Berlin Wasser Betriebe } \\
\text { (Heinzmann 2001) }\end{array}$ & 12.4 & $\begin{array}{l}\text { Large } r \text { crystalline } \\
\text { chips (up to } 8 \mathrm{~mm} \text { ) } \\
\text { with some smaller } \\
\text { dark particles }\end{array}$ \\
\hline $\begin{array}{l}\text { Sewage recovered } \\
\text { calcium } \\
\text { phosphate }\end{array}$ & $\begin{array}{l}\text { Calcium phosphate recovered by the } \\
\text { full-scale Crystallactor process at the } \\
\text { Geestmerambacht municipal sewage } \\
\text { treatment works, The Netherlands } \\
\text { (Gaastra et al. 1998, Giesen 1999) }\end{array}$ & 8.3 & $\begin{array}{l}\text { Dark brown moist } \\
\text { powder, strong foul, } \\
\text { unidentified smell }\end{array}$ \\
\hline $\begin{array}{l}\text { Synthetic iron } \\
\text { phosphate }\end{array}$ & $\begin{array}{l}\text { Laboratory synthesised by Cranfield } \\
\text { University, UK using commercial } \\
\text { water treatment iron chloride } \\
\text { (Analar grade) and pure hydrogen } \\
\text { phosphate solution }\end{array}$ & 14.1 & Pale brown powder \\
\hline
\end{tabular}


Table 2: Properties of the two soils used in the pot experiments

\begin{tabular}{|l|c|c|c|}
\hline & Units & Soil 1 & Soil 2 \\
\hline $\mathrm{pH}$ & & 6.61 & 7.08 \\
\hline Phosphorus (Olsen) & $\mathrm{mg} \mathrm{P} \mathrm{L}^{-1}$ & 28.0 & 11.2 \\
\hline Potassium (AN extraction) & $\mathrm{mg} \mathrm{K} \mathrm{L}^{1}$ & 265 & 92 \\
\hline Magnesium (AN extraction) & $\mathrm{mg} \mathrm{Mg} \mathrm{L}^{-1}$ & 155 & 59 \\
\hline Organic carbon C) & $\% \mathrm{C}$ & 1.0 & 1.8 \\
\hline Sand & $\%$ & 61 & 60 \\
\hline Silt & $\%$ & 23 & 11 \\
\hline Clay & $\%$ & 16 & 29 \\
\hline Texture & & Sandy loam & Sandy clay loam \\
\hline
\end{tabular}

Before sowing the seed, basal nutrients, $0.05 \mathrm{~g} \mathrm{~N}$ per pot and $0.1 \mathrm{~g} \mathrm{Mg}$ per pot, were mixed with the soil as ammonium nitrate and magnesium sulphate. This was followed by topdressing with $0.15 \mathrm{~g} \mathrm{~N}$ per pot and $0.08 \mathrm{~g} \mathrm{~K}$ per pot after every harvest as ammonium nitrate and potassium sulphate and by top-dressing with $0.05 \mathrm{~g} \mathrm{Mg}$ per pot as magnesium sulphate after harvests 2 and 4 . The pots were watered with rain water applied to the surface as required. The amount was such that the grass never wilted but through-drainage into the saucers in which the pots stood was kept to a minimum. Any leachate was returned to the pot.

The grass was harvested at 20, 38, 49/50, 66, 85 and 100 days after sowing. Grass samples were dried overnight at $100^{\circ} \mathrm{C}$, weighed and then milled before chemical analysis for total $\mathrm{P}$ concentration. P offtake was calculated on a pot basis by multiplying DM yield by \% P. Samples taken at 100 days were not analysed for P as, by harvest 6, dry DM yield responses had declined on both soils and there were no significant treatment differences in grass $\% \mathrm{P}$ at harvest 5 .

\section{RESULTS AND DISCUSSION}

The data sets comprised grass DM yield at harvests 1 to 6 and P offtake at harvests 1 to 5 . Results presented in Table 3 are for total DM yield and for total P offtake. P concentration in the DM, which is not shown, tended to decline during the experiment from 7000 to $9000 \mathrm{mg} \mathrm{P}$ $\mathrm{kg}^{-1}$ for soil 1 and 4000 to $7000 \mathrm{mg} \mathrm{P} \mathrm{kg}^{-1}$ for soil 2 at harvest 1 to between 3700 and $5300 \mathrm{mg} \mathrm{P}$ $\mathrm{kg}^{-1}$ for both soils at harvest 5 . There were few significant treatment differences in $\% \mathrm{P}$, mainly lower concentrations with the sewage recovered calcium phosphate and the synthetic iron phosphate. However, these did not lead to significant differences in P offtake. Although a well tested pot experiment technique was used, experimental error reflected in the standard error per pot tended to be somewhat higher than normally expected. We can offer no explanation for this.

\section{Dry matter yield and $P$ offtake}

At the lower amounts of P applied as MCP, both DM yield and P offtake were smaller on soil 2 which had the least Olsen P. Differences between the two soils were less at the higher levels of applied $\mathrm{P}$. This suggests that the small difference in $\mathrm{pH}$ and the larger difference in Olsen $\mathrm{P}$ between the soils did not affect the DM yield and P offtake that could be achieved under the conditions of these pot experiments. This conclusion is supported by DM yields and $\mathrm{P}$ offtakes with MCP at 0.109 and $0.131 \mathrm{~g} \mathrm{P}$ per pot. Both were a little lower with 0.131 than with $0.109 \mathrm{~g}$ $P$ per pot but the differences were not significant suggesting that the maximum DM yield and $\mathrm{P}$ offtake had been reached. 
Table 3: Total dry-matter yield of ryegrass and total $P$ offtake in the grass for MCP and precipitated phosphates

\begin{tabular}{|l|l|l|l|l|l|l|}
\hline & \multicolumn{3}{|c|}{$\begin{array}{c}\text { Total dry-matter } \\
\text { yield (g per pot) }\end{array}$} & \multicolumn{3}{c|}{$\begin{array}{c}\text { Total P offtake } \\
\text { (mg per pot) }\end{array}$} \\
\hline & Soil 1 & Soil 2 & Mean & Soil 1 & Soil 2 & Mean \\
\hline & & & & & & \\
\hline Control & 3.25 & 2.56 & 2.91 & 16.35 & 9.38 & 12.87 \\
\hline & & & & & & \\
\hline MCP 0.044 g P per pot & 6.53 & 3.66 & 5.10 & 23.94 & 12.55 & 18.25 \\
\hline MCP 0.065 g P per pot & 6.92 & 5.19 & 6.06 & 25.79 & 18.53 & 22.16 \\
\hline MCP 0.087 g P per pot & 6.19 & 5.23 & 5.71 & 27.36 & 22.46 & 24.91 \\
\hline MCP 0.109 g P per pot & 6.66 & 7.00 & 6.83 & 27.66 & 32.22 & 29.94 \\
\hline MCP 0.131 g P per pot & 5.63 & 6.10 & 5.86 & 26.80 & 26.10 & 26.45 \\
\hline & & & & & & \\
\hline MCP 0.087 g P per pot (from response curve) & 6.66 & 5.97 & 6.28 & 27.14 & 25.35 & 26.28 \\
\hline & & & & & & \\
\hline Precipitated phosphates at 0.087 g P per pot: & & & & & & \\
\hline Synthetic struvite no. 1 & 6.40 & 7.25 & 6.83 & 29.68 & 29.75 & 29.72 \\
\hline Synthetic struvite no. 2 & 6.58 & 7.40 & 6.99 & 28.75 & 30.01 & 29.38 \\
\hline & & & & & & \\
\hline Struvites recovered from: & & & & & & \\
\hline Sewage (no. 1a) & 7.00 & 5.87 & 6.44 & 30.44 & 24.10 & 27.27 \\
\hline Sewage (no. 1b) & 6.40 & 6.11 & 6.26 & 27.09 & 24.84 & 25.97 \\
\hline Sewage (no. 3) & 6.68 & 5.88 & 6.28 & 29.70 & 23.92 & 26.81 \\
\hline Corn steep (no. 2) & 6.00 & 6.18 & 6.09 & 26.01 & 26.48 & 26.25 \\
\hline Dye industry (no. 4) & 6.35 & 5.89 & 6.12 & 28.53 & 24.75 & 26.64 \\
\hline Veal manure (potassium struvite no. 5) & 6.91 & 5.99 & 6.45 & 31.13 & 22.22 & 26.68 \\
\hline Sewage deposit (no. 6) & 6.62 & 5.11 & 5.87 & 28.97 & 20.46 & 24.72 \\
\hline & & & & & & \\
\hline Recovered calcium phosphate & 6.09 & 6.83 & 6.46 & 21.64 & 20.45 & 21.05 \\
\hline Synthetic iron phosphate & 6.94 & 7.09 & 7.02 & 25.20 & 22.68 & 23.94 \\
\hline SE/plot (33 D.F.) & 1.126 & 1.557 & 1.359 & 4.295 & 5.089 & 4.709 \\
\hline
\end{tabular}

\section{Yield and $P$ offtake responses to $P$ applied as MCP}

Curvilinear relationships between total DM yield and P applied and between total $\mathrm{P}$ offtake and $\mathrm{P}$ applied were apparent for each soil and for mean data from the two soils. Cubic regression functions, fitted to the data in Table 3, were used to describe these relationships. Values for total DM yield and total P offtake for MCP applied at $0.087 \mathrm{~g}$ P per pot calculated from the regression equations, provided a more representative basis for comparing $\mathrm{MCP}$ and the precipitated phosphates than did the measured values for MCP at $0.087 \mathrm{~g}$ P per pot.

$\mathrm{P}$ offtake response (the difference in $\mathrm{P}$ offtake between a treatment and the untreated control) tended to increase during the course of the pot experiments. Apparent P recovery calculated from total P offtake, was $12.7 \%$ for soil 1 and $15.0 \%$ for soil 2, typical for pot experiments using ryegrass as the test crop and for many arable crops in field experiments. 


\section{Yield and $P$ offtake response with $P$ applied as precipitated phosphates}

There were no significant $(\mathrm{P}<0.05)$ differences in total $\mathrm{DM}$ yield between the different precipitated phosphates or between any of the precipitated phosphates and MCP applied at $0.087 \mathrm{~g} P$ per pot (Table 3 ). For the precipitated phosphates, total $\mathrm{P}$ offtake response over 5 harvests ranged from 5.3 to $14.8 \mathrm{mg} P$ per pot for soil 1, equivalent to an apparent recovery of 6 to $17 \%$ of the applied P. For soil 2, total P offtake response ranged from 11.1 to $20.6 \mathrm{mg} P$ per pot, equivalent to an apparent recovery of 13 to $24 \%$ of the applied $\mathrm{P}$.

$\mathrm{P}$ offtake for both synthetic struvites was higher than that for MCP at $0.087 \mathrm{~g}$ P per pot though not significantly so. For the recovered struvites, $\mathrm{P}$ offtake was similar to that for MCP at 0.087 $\mathrm{g} P$ per pot although in soil 2, P offtake recorded for recovered struvite no. 6 was lower than that for MCP (though the difference was not statistically significant). The potassium struvite (recovered struvite no. 5) gave a $\mathrm{P}$ offtake apparently higher than that for MCP in soil 1 but similar to MCP in soil 2. The sewage recovered calcium phosphate gave the lowest $\mathrm{P}$ offtake in both soils, significantly $(\mathrm{P}<0.05)$ lower than that for MCP in soil 1.

For the precipitated phosphates, there were some small differences in DM yield and $\mathrm{P}$ offtake between the two soils. However, these differences were not consistently in favour of one soil or the other and fell within the range of experimental error. It is, therefore, appropriate to consider the mean of the two soils. The apparent effectiveness (E) of the precipitated phosphates relative to that of MCP was expressed as a percentage by $E=(\mathrm{M} / 0.087) \times 100$ where $\mathrm{M}$ is the rate of $\mathrm{P}$ applied as $\mathrm{MCP}$ (from the regression equation) corresponding to the same total $\mathrm{P}$ offtake given by the precipitated phosphate.

Both synthetic struvites applied at $0.087 \mathrm{~g} \mathrm{P}$ per pot gave very similar DM yields and $\mathrm{P}$ offtakes which were larger than those recorded for MCP at the same rate of application but the differences were not statistically significant. The value of $E$ for these materials could not be calculated as the recorded $\mathrm{P}$ offtakes were slightly greater than the maximum values from the regression equations.

DM yields and $\mathrm{P}$ offtakes were similar for the three struvites recovered from municipal sewage (nos 1a, 1b and 3) and in the ranges 6.26 to $6.44 \mathrm{~g}$ DM per pot and 25.97 to $27.27 \mathrm{mg}$ P per pot. These values were not significantly different to those for MCP at $0.087 \mathrm{~g} \mathrm{P}$ per pot predicted using the regression equations. Values of $\mathrm{E}$ for these materials were $98 \%$ to $109 \%$.

DM yields given by the struvites recovered from corn steep (no. 2) and the dye industry (no. 4) were only a very little smaller than those given by struvites recovered from sewage and $P$ offtakes were the same. Values of E were $104 \%$ and $103 \%$ respectively.

Potassium struvite derived from veal manure (no. 5) gave very similar DM yields and $\mathrm{P}$ offtakes to the other recovered struvites and a value of $103 \%$ for $\mathrm{E}$.

The spontaneously occurring deposit from sewage (no. 6), mainly struvite judged by its total $\mathrm{P}$ content, gave slightly lower DM yields and P offtakes than did the other recovered struvites. The E value was somewhat lower at $90 \%$.

The recovered struvites gave consistently smaller DM yields than the synthetic struvites but the differences were not statistically significant. This suggests that the recovered struvites might have slightly lower $\mathrm{P}$ availability than the synthetic struvites, a conclusion supported by the lower yields given by the spontaneously occurring struvite deposit. These small differences may be due to crystal size. If so, this would suggest that struvite precipitation from waste water streams should be carefully controlled. Nevertheless, the effectiveness of these struvites as sources of $\mathrm{P}$ for plants was very similar to that of MCP. 
The recovered calcium phosphate gave the lowest recorded total $\mathrm{P}$ offtake of the precipitated phosphates and a value of $69 \%$ for $\mathrm{E}$.

The iron phosphate gave somewhat larger DM yields but slightly smaller P offtakes to those given by MCP at $0.087 \mathrm{~g}$ P per pot with a value of $85 \%$ for E. It has generally been considered that iron phosphates are insoluble and that the $\mathrm{P}$ they contain is unavailable to plants. This was not so for this synthetic iron phosphate. Recently, Richards and Johnston (personal communication) found that a part at least of the water-insoluble $\mathrm{P}$ fraction of triple superphosphate was available to plants. This fraction also was probably largely iron phosphates. Some research is needed on iron phosphates precipitated from waste water using ferrous or ferric salts. The plant availability of the P may depend on the degree of hydration and perhaps the extent of ageing and slow transformations of the iron phosphate.

\section{ACKNOWLEDGEMENTS}

The authors thank CEEP, European Fertiliser Manufacturers Association, Thames Water, Anglian Water and Berlin Wasser Betreibe who funded this work established to ascertain the availability of $P$ in a range of recovered phosphates from different sources. The pot trials were conducted by AgroChemical Experimentation Ltd and the chemical analyses by Natural Resource Management Ltd.

\section{REFERENCES}

Gaastra S., Schemen R., Bakker P. and Bannink M. 1998. Full scale phosphate recovery at sewage treatment plant Geestmerambacht, Holland. $1^{\text {st }}$ International Conference on Phosphorus Recovery for Recycling, Warwick University, UK.

(Available at http://www.nhm.ac.uk/ mineralogy/P-recovery/).

Gaterell MR., Gay R., Wilson R., Gochin RJ. and Lester JN. 2000. An economic and environmental evaluation of the opportunities for substituting phosphorus recovered from wastewater treatment works in existing UK fertiliser markets. Environmental Technology 21, 1067 - 1084 .

Ghosh GK., Mohan KS. and Sarkar AK. 1996. Characterisation of soil-fertilizer P reaction products and their evaluation as sources of $\mathrm{P}$ for gram (Cirer arietinum L.). Nutrient Cycling in Agroecosystems 46, 71 - 79.

Giesen A., 1999. Crystallisation process enables environmental friendly phosphate removal at low costs. Environmental Technology 20, 759-775.

Goto I., 1998. Application of phosphorus recovered from sewage plants. Environmental Conservation Engineering 27, 418-422.

Heinzmann B., 2001. Phosphorus recovery in wastewater treatment plants. $2^{\text {nd }}$ International Conference on Phosphorus Recovery for Recycling, Noordwijkerhout, The Netherlands. (Available at http://www.nhm.ac.uk/mineralogy/P-recovery/)

Koritskaya TD. and Remen RE., 1962. Magnesium ammonium phosphate as a complex fertilizer.Zh. Vses. Khim. Obshchestra in D. I. Mendeleeva 7, 520 - 523.

Matsumiya Y., Yamasita T. and Nawamura Y., 2000. Phosphorus removal from sidestreams by crystallisation of magnesium ammonium phosphate using seawater. Journal of the Chartered Institution of Water and Environmental Management 14, 291-296.

Murray J., 1858. Notices and Abstracts. British Association for the Advancement of Science, Report of the $27^{\text {th }}$ Meeting pp $54-55$. 
Schuiling RD. and Andrade A., 1999. Recovery of struvite from calf manure. Environmental Technology 20, 765-768.

Taruya T., Ueno Y. and Fujii M., 2000. Development of phosphorus resource recycling process from sewage. $1^{\text {st }}$ World Water Congress, International Water Association, 3-7 July 2000.

Ueno Y. and Fujii M., 2001. 3 years operating experience selling recovered struvite from fullscale plant. Environmental Technology 22, 1373-1381.

Villalba G., Chimenos JM., Fernández A., Segarra MI. and Espiell F., 2001. Removal of ammonium and phosphates from wastewater resulting from the production of carmin red dye from cochineals. $2^{\text {nd }}$ International Conference on Phosphorus Recovery for Recycling, Noordwijkerhout, The Netherlands. 